\title{
RESEMBLANCE OF INDIRECTNESS IN POLITENESS OF EFL LEARNERS' REQUEST REALIZATIONS
}

\author{
Indawan Syahri \\ Universitas Muhammadiyah Palembang, Indonesia \\ email: indawansyahri_ump@yahoo.co.id
}

\begin{abstract}
Politeness principles are universally utilized by the speakers of any language when realizing various speech acts. However, the speakers of particular languages relatively apply politeness due to the cultural norms embedded. The present study attempts to delineate how the Indonesian learners of English (ILE) apply the politeness principles in request realizations. Specifically it devotes to the types of politeness strategies applied and resemblance of the indirectness in politeness strategies in requesting acts. The FTAs and indirectness are the theoretical bases used to trace the typologies of both politeness and request strategies. The data werere collected by means of certain elicitation techniques, i.e. DCTs and Role-plays. The analyses werere done through three stages; determining request strategies, politeness strategies, and resemblance of indirectness in politeness. The results show that the indirectness generally is parallel to politeness. Besides, some pragmatic transfers are found in terms of applying native-culture norms in realizing target speech acts.
\end{abstract}

Key words: resemblance, indirectness, politeness principles

\section{KESAMAAN KETIDAKLANGSUNGAN DALAM REALISASI KESANTUNAN BERBAHASA PERMOHONAN}

\begin{abstract}
Prinsip-prinsip kesantunan secara umum digunakan oleh penutur bahasa manapun saat melakukan beragam tindak tutur. Akan tetapi, penutur bahasa tertentu menerapkan kesantunan sesuai dengan norma-norma budaya yang berlaku. Kajian ini berusaha untuk menggambarkan bagaimana pembelajar bahasa Inggris Indonesia menerapkan prinsip-prinsip kesantunan dalam melakukan permintaan. Kajian ini khususnya meneliti jenis-jenis strategi kesantunan yang diterapkan dan kemiripan ketidaklangsungan dalam strategi kesantunan dalam tindak permintaan. Tindakan yang mengancam seseorang kehilangan wajah (FTA) dan ketidaklangsungan adalah dasar teori yang digunakan untuk menelusuri tipologi dari kesantunan dan strategi permintaan. Data dikumpulkan dengan menggunakan beberapa teknik pengumpulan data, yaitu $D C T$ (Discourse Completion Test) dan bermain peran. Analisa-analisanya dilakukan melalui tiga tahapan: menentukan strategi permintaan, strategi kesantunan, dan kemiripan ketidaklangsungan dengan kesantunan. Hasilnya menunjukkan bahwa ketidaklangsungan secara umum sejajar dengan kesantunan. Selain itu, beberapa perpindahan pragmatik ditemukan dalam hal penerapan norma-normal budaya lokal dalam mencapai target dari tindak tutur.
\end{abstract}

Katakunci: kemiripan, ketidaklangsungan, prinsip-prinsip kesantunan

Requests are face-threatening acts (FTAs), threatening the hearer's (H's) negative face (Brown \& Levinson, 1987). The more threatening is an act, the more polite and indirect are the means used to accomplish it. So those who perform a request need to reduce the level of imposition created by an act being requested in order to save the H's face and get compliance with a request. Here is where the notion of politeness 
comes to play. Specifically, in terms of directness and indirectness, the learners' cultural aspects influence these acts. It was generally found that the natives of oriental languages use an indirect approach in making English requests. For instance, Chinese come to the point at the end when making requests (Yuxin \& Cheng, 2002). It is claimed that politeness is demonstrated in Asia through honorification; that is, the use of respect markers with nouns, verbs, and modifiers to show deference toward addressees or referents (Bonvillain, 2003:88). The present study attempts to observe how politeness essentially plays its roles in the learners' requesting acts.

Requests are particularly sensitive to contexts of speaking and to specific social characteristics of the requesters. On the one hand, speaker (S) should phrase requests so as to have the greatest likelihood of a positive result, namely, compliance; on the other hand, he must be sensitive to H's feelings. $S$ needs to navigate between two extremes of clarity, that is to say, making the request clear enough in order to be comprehended by the $\mathrm{H}$ and paying attention to the H's needs not to be imposed. $S$ needs to maintain an appropriate degree of imposition when making requests. Moreover, situational variables, i.e. social distance (a symmetric relation between speaker and hearer) and power (an asymmetric relation between speaker and hearer) between $\mathrm{S}$ and $\mathrm{H}$ also affect the patterns, degree of directness, mitigation, and maximization in issuing requests (Blum-Kulka, et al., 1989:3).

Directness tends to rise with increase in familiarity, as well as with the change in setting from the public to the private. Cultural norms apparently influence the interpretation of these variables. Degree of social distance depends on cultural notions of familiarity or formality involved in any given relationship; relative power of $S$ and $\mathrm{H}$ is contingent on social segmentation and the assignment of greater or lesser rights and obligations to members of distinct groups; and relative degree of FTA is only appropriate in the context of cultural assumptions about the risks and costs of given behaviors (Bonvillain, 2003:129). In EFL, the learners' awareness of the situational factors affects the appropriateness of requests realized. In fact, the learners' native-culture norms are sometimes distinct from those of TL culture. The distinction potentially causes the difficulties for the learners in studying and as a result, they often make inappropriate requests. There is a tendency that FL learners' acts are influenced by their native-culture norms.

Based on the previous statements, this study focuses on examining requests realized by Indonesian learners of English in elicited situations. The study tries to answer the main problem, that is, "How do Indonesian learners of English (ILE) apply politeness principles in their request realization?" Then, it specifies to provide answers to the following questions "What are the types of politeness strategies applied by the learners in requesting acts?" and "How does the indirectness resemble politeness strategies in requesting acts?"

\section{METHOD}

For this purpose, the study focused on the acts realized by ILE who had good English proficiency. Accordingly, the subjects recruited for the study were undergraduate students of an English Study Program who had TOEFL-like scores of at least 450. The subjects were considered as "proficient" learners assumed to have relatively sufficient linguistic knowledge for realizing English request realizations. They were the students of Sriwijaya University (a state university located in Indralaya, South Sumatra Province, Indonesia). There were 68 students selected as the subjects of the study:

There were two types of instruments used in collecting data. The first instrument was the DCT questionnaires which consisted of a number of certain situations 
and were followed by blank spaces on which the subjects were asked to provide an appropriate linguistic form of requesting acts - as though they were the speakers in real-life interactions, for instance:

Situation 1: You are preparing for a midterm examination which is scheduled tomorrow. It's about 9 p.m. A new neighbor about your age whom you do not already know is playing music very loudly. So you cannot concentrate on studying. You want this neighbor to turn down the music. What would you say to get the neighbor to do this favor?

The DCT descriptions explicitly told the subjects about the roles that they play in such situations. The situational variables dealing with social distance (familiarity) and social power (dominance) were embedded. Based on the situations and roles described, the subjects were asked to produce requests in the blank spaces provided (see Appendix 1).

As for the second instrument, out of 68 subjects, 36 (26 fifth-semester and 10 seventh- semester students) were selected as the participants of the role-plays. They were asked to produce dialogues based on the scenarios written in the role-plays. The procedures were conducted very carefully to maintain continuous participation of all the participants. In order to prevent repeating other participants' utterances, the researcher put each scenario on a strip of paper and rolled the papers into coupons. They were given opportunities to take three or four coupons randomly and produce dialogues in front of the class with their fellow students. They practiced the roleplays in pairs. These stages were done several times in several meetings until every subject played at least 6 of the 10 scenarios provided (See Appendix 2).

To identify the resemblance indirectness in politeness strategies, the study made use of the theories of FTAs (Brown
\& Levinson, 1987) and request strategy that was exposed by Blum-Kulka (1989) and Faerch and Kasper (1989). The following are the summaries of sub-levels of strategy types in the scale of indirectness.

\section{Direct Strategies}

a. Mood derivable (The grammatical mood of the verb in the utterance marks its illocutionary force as a request)

Leave me alone.

Clean up this mess, please.

b. Explicit performatives (The illocutionary force of the utterance is explicitly named by the speakers)

I'm asking you to clean up the kitchen.

I'm asking you not to part the car here.

c. Hedged performatives (Utterances embedding the naming of the illocutionary force)

I'd like to ask you to clean the kitchen.

I'd like you to give your lecture a week earlier.

d. Obligation statements/OS (The illocutionary point is directly derivable from the semantic meaning of the locution)

You'll have to clean up the kitchen.

Ma'am, you'll have to move your car.

e. Want statements (The utterance expresses the speaker's intentions, desire or feeling vis a vis the fact that the hear do X)

I really wish you'd clean up the kitchen. I really wish you'd stop bothering me.

\section{Conventionally indirect strategies}

a. Suggestory formulae (The sentence contains a suggestion to $\mathrm{X}$ )

How about cleaning up?

Why don't you get lost?

So, why don't you come and clean up the mess you made last night?

b. Query preparatory (The utterance contains reference to preparatory conditions, such as ability or willingness, the possibility of the act being performed, as conventionalized in any specific language) 
Could you clean up the kitchen, please? Would you mind moving your car, please?

\section{Non-conventionally indirect strategies (hints)}

a. Strong hints (The utterances contain partial reference to object or to elements needed for the implementation of the act, directly pragmatically implying the act)

You have left the kitchen in a right mess.

b. Mild hints (Utterances that make no reference to the request proper or any of its elements but are interpretable through the context as requests, indirectly pragmatically implying the act)

I'm a nun (in response to a persistent hassler).

\section{RESULTS AND DISCUSSION Politeness Strategies}

It was found that the subjects utilized certain strategies which contained politeness values which also considered the efficiency of the request realizations in terms of clarity and imposition to Hs. The findings dealt with the occurrences of baldon-record ( $2 \%$ in DCT \& $2 \%$ in Roleplays), positive politeness (3\% in DCT \& $23 \%$ in Role-plays), negative politeness ( $85 \%$ in DCT \& $46 \%$ in Role-plays), and off-record strategies (2\% in DCT \& $11 \%$ in Role-plays). Besides, it was identified that some Ss combined positive with negative politeness strategies, i.e. $8 \%$ in DCT and $18 \%$ in Role-plays.

Table 1 Distributions of politeness strategies in DCT

\begin{tabular}{ccccccc}
\hline Situations & Bald on & Positive & Negative & $\begin{array}{c}\text { Combined } \\
\text { Positive with } \\
\text { Negative }\end{array}$ & Off-record & TOTAL \\
& Record & & & Nolitens Strategies & \\
\hline 1 & 7 & 4 & 42 & 6 & 3 & 62 \\
2 & 0 & 1 & 61 & 5 & 0 & 67 \\
3 & 1 & 6 & 58 & 0 & 0 & 65 \\
4 & 1 & 2 & 63 & 1 & 0 & 67 \\
5 & 0 & 0 & 63 & 3 & 1 & 67 \\
6 & 1 & 5 & 62 & 0 & 0 & 68 \\
7 & 1 & 0 & 55 & 10 & 0 & 66 \\
8 & 0 & 1 & 65 & 0 & 0 & 66 \\
9 & 1 & 2 & 64 & 0 & 1 & 68 \\
10 & 1 & 4 & 31 & 27 & 5 & 68 \\
11 & 0 & 1 & 63 & 0 & 0 & 64 \\
12 & 0 & 0 & 58 & 8 & 0 & 66 \\
13 & 4 & 3 & 56 & 1 & 4 & 68 \\
14 & 0 & 2 & 50 & 12 & 4 & 68 \\
15 & 1 & 1 & 54 & 6 & 3 & 65 \\
Total & 18 & 32 & 845 & 79 & 21 & 995 \\
Average & .02 & .03 & .85 & .08 & .02 & 100 \\
\hline
\end{tabular}

\section{a. Bald-on-record Politeness Strategies}

Some of the subjects selected the bald-onrecord strategy in realizing requests. Most of them appeared in Situation 1 and Scenario 9. In Situation 1: want a new neighbor to turn down the music, they ( $11 \%$ of the 62 subjects) used the bald-onrecord due to the situation in which they made requests to unfamiliar $\mathrm{Hs}$, but had no dominance. Besides, the condition which illustrated that the Ss were disturbed by the noise of their new neighbor's music such as in examples:

(1) Turn down the music, please

(2) Please turn the music down

The Ss in this case realized their request without using redressive actions. 
They used imperatives to convey the message. It occurred due to the situations that triggered to do so. The presence of 'please' was unique in this situation. They, though, were 'not in good mood' they could commence or end their imperatives with 'please'. That is why Blum-Kulka (1992) considered 'mood derivable' as one of direct strategies. It really derived from Ss' moods. It also occurred in Scenario 4 which had the same situational variables elicited in the role-plays.

Among the 4 bald-on-record strategies, 2 appeared in Scenario 9, for instance, one of the Ss realized a request as in the following excerpt:

(3) A: Excuse me // I have some problems / to choose shoe.

B: Okay / eh / what's your problem?

A: eh / I'm confused to choose / good shoes / good shoes for my feet.

B: Okay / let me see // I think / these shoes / eh / more / more / more / available in your feet.

A: Is it?

B: Yes // because / look at the color / I think / it's very / very comfortable / in your feet / more than / more than these shoes.

A: Okay / let me try.

Okay / I think / it's my / my choice to / buy // and then / how much these shoes?
B: These shoes is / one hundred rupiahs.

A: Okay / thank you.

B: You're welcome.

This S started their dialogue by saying "Excuse me // I have some problems to choose shoe." It was used as an attention getter, the utterance 'I have some problems to choose shoe' seemed indirect. Then, when coming to the head act of the request "let me try", the S apparently used direct strategy in the form of mood derivable. Concomitantly, he/she applied Bald-onrecord politeness strategy. He/she directly uttered it without redressive action, without considering H's face wants. He/she did not consider that the $\mathrm{H}$ needed to be given approval (positive face) or the $\mathrm{H}$ needed not to be imposed (negative face). It appeared in $2 \%$ of the 203 dialogues in role-plays.

The bald-on-record strategies used by the subjects pertained to the directness of realizing requests. The more direct the requests realized the more bald-on-record politeness strategies were utilized by the Ss. It was shown by the previous examples. The Ss of (1), (2), and (3) used bald-onrecord politeness strategies in the forms of direct strategies.

Table 2 Distributions of politeness strategies in role-plays

\begin{tabular}{ccccccc}
\hline Scenarios & $\begin{array}{c}\text { Bald on } \\
\text { Record }\end{array}$ & Positive & Negative & $\begin{array}{c}\text { Combined } \\
\text { Positive with } \\
\text { Negative }\end{array}$ & $\begin{array}{c}\text { Off- } \\
\text { record }\end{array}$ & TOTAL \\
\hline 1 & 0 & 4 & 7 & 5 & 0 & 16 \\
2 & 0 & 6 & 15 & 2 & 0 & 23 \\
3 & 0 & 2 & 16 & 0 & 3 & 21 \\
4 & 1 & 1 & 12 & 5 & 1 & 22 \\
5 & 0 & 4 & 12 & 4 & 2 & 20 \\
6 & 0 & 6 & 8 & 6 & 0 & 18 \\
7 & 1 & 9 & 7 & 3 & 1 & 24 \\
8 & 0 & 3 & 0 & 0 & 1 & 18 \\
9 & 2 & 3 & 12 & 6 & 0 & 203 \\
10 & 0 & 8 & 4 & 6 & 23 & 100 \\
\hline Total & 4 & 46 & 93 & 37 & .11 & \\
\hline
\end{tabular}




\section{b. Positive Politeness Strategies}

One of the redresseive actions is the positive politeness strategy. The Ss attempt to save the Hs' positive face wants (BlumKulka, 1992). In the present study, the subjects used the positive politeness strategy in some of their requests. The subjects only utilized the positive politeness strategy in some requests elicited by DCT questionnaires. There were $3 \%$ among the 995 requests. For instance, one of the subjects in Situation 3 made a request as in (4).

(4) Sir, please let me take this course. I like this course very much.

The $\mathrm{S}$ in this case utilized the direct strategy and embedded the request with an utterance "I like this course very much" to save the H's positive face. Though it requested to an unfamiliar and superior $\mathrm{H}$, the $\mathrm{S}$ just considered the H's positive face by adding the request with the supportive move and further completed with intensifier 'very much'. The move embedded was aimed to praise the $H$. The $S$ showed he/she was optimistic that the request would end with compliance.

(5) You're really good, I think, and I don't think I am. I need to get ready for the exam and I need you to help me for it.

Similarly, the $S$ in (5) initiated the request using a sweetener "You're really good, I think, and I don't think I am". The $\mathrm{S}$ meant to maximize praise to $\mathrm{H}$ as also related to one of the Leech's (1983) politeness maxim, i.e. Approbation Maxim (APM). At the same time, the $\mathrm{S}$ had saved the H's positive face. He/she exaggerated interest in $\mathrm{H}$ by uttering "You're really good". Besides, "I don't think I am" strengthened the reasons why $\mathrm{S}$ wanted $\mathrm{H}$ to do the act requested.
Moreover, the Ss realized many of their requests using the positive politeness in Role-plays. There were $23 \%$ of the 203 dialogues. Most of the Ss utilized the positive politeness strategy in Scenarios 7: ask a close friend to go to movie and 10 in which they were elicited to ask the shop assistant in a music store to let $\mathrm{S}$ try on listening to a cassette. For instance, one of the Ss realized a request as follows:

(6) A: GUSTI! / as usual / I want to buy / - I want to buy this cassette // now / I would you like / to try it first / before I buy it / I just want to make sure / that / if the cassette / is running well.

B: Yeah / WESTLIFE / it's a good cassette.

A: Okay / I will try it $\mathrm{Oh} /$ the song is good / I'll *take it*

B: ...

A: Okay / thank you.

B: You're welcome.

This sort of strategy was competitively used by the $S s$ in realizing the requests in Scenarios 1, 2, 7 and 10 in which the Ss made requests to the Hs who were not socially distant and dominant. Both Ss and Hs had friendly good fellowship or at least know each other very well so that why the strategy employed had something to with Rule 3 what so-called camaraderie by Lakoff (1990). One of the Ss in Scenario 1 realized a request with this principle as shown in (7).

(7) A: WINDA!

B: Hi / HESTI // you look so pale // what happen to you?

A: I have some troubles

$\mathrm{B}$ : *What* is the trouble

A: *Yeah* / I am in hurry now / because of / dropping my father to go to the station.

B: ... 
A: I am in hurry / I will be late if I take a bus from here // Can I depend on you?

The $\mathrm{S}$ greeted the $\mathrm{H}$ with the exact name 'WINDA!' which functioned as an alerter. It was responded by the $\mathrm{H}$ with the exact name as well, then, the $\mathrm{H}$ added with a warming greeting and drew an attention by say "... you look so pale // what happen to you?" It also signaled solidarity. After a series of turns, the $\mathrm{S}$ realized a request which was seemingly enacted indirectly "Can I depend on you?" The head act was in the form of query preparatory using modal can which was often applied in negative politeness, but observing the supportive moves embedded it attempted to save the H's positive face.

It also occurred in other scenarios. In Scenario 2, for instance, some Ss utilized the positive politeness strategy in their requests.

(8) A: Sh / sh / YENI! / Come here / I need help / I forgot to bring my pen

B: So?

A: Can you help me?

B: Emm.

A: Please! / I need your pen /

B: Emm

A: You are a good girl / are you / aren't you?

B: Of course / I am / here it is.

A: Thank you very much.

One of them applied a positive strategy in the form of friendly in-group marker "Sh / sh / YENI! /Come here / I need help / I forgot to bring my pen" before he/she realized the request "Can you help me?" as in excerpt (8). The S not only started friendly supportive move, but also embedded a sweetener "You are a good girl / are / you / aren't you?" after the head act, besides, it was used as a joke.

Positive politeness strategies, in short, resemble the direct strategies such as mood derivable as in (4), want statements in (5), and hedged performatives in (6). However, the query preparatory as one of the conventionally indirect strategies which is claimed as one of the negative politeness strategies is untenable because some of the query preparatory strategies are used to save the Hs' positive face like in excerpt (8). The presence of supportive moves attempts to save the Hs' positive face wants, i.e. desire for approval, intimacy, and solidarity.

\section{c. Negative Politeness Strategies}

The subjects opted to realize requests using the negative politeness strategy most frequently. $85 \%$ of the request in DCT and $44 \%$ of the dialogues containing requests in role-plays were made by means of saving the Hs' negative face, i.e. their right not to be imposed by the requests realized. The subjects utilized these strategies dominantly across all the situations. Regardless in which the situational variables they were in most of the subjects made use of these strategies. It was relevant to their request strategies they used commonly in making requests. It was apparently found that most subjects in the present study realized requests using the conventionally indirect strategy in the form of query preparatory. Further, it was claimed that query preparatory included in negative politeness strategies. In short, conventional indirectness itself is one of the negative politeness strategies (Brown \& Levinson, 1987:132).

\section{(9) Can you turn down your music, please!} I am studying

Imposition was considered as the main factor that assembled in realizing requests. The Ss attempted to lower the ranks of imposition of their requests as the responses to all the situations in DCTquestionnaires. They were elicited to realize requests under several situations whose various situational variables, though, they evidently applied the negative politeness strategy dominantly. In Situation 
1 , for instances, among the 62 requests there were $68 \%$ requests that applied the negative politeness as in (9). Some even made very polite requests using modal could, though the requests were addressed to persons of equal social status.

Most $(91 \%)$ of the subjects utilized the negative politeness strategy when realizing their requests in Situation 2 in which they were elicited to borrow pens from their friends. There were actually no social distance and dominance between interlocutors in this context, however they were found to use these strategies.

(10) Excuse me. Could you lend me your pen for a moment, please?

It referred to preparatory conditions, i.e. asking ability to comply with the requests. Some used negative politeness using modal could as in (10). These sorts of requests emerged frequently in this situation. It also happened in other situations elicited by means of both DCT and
Role-plays. Most of the Ss utilized negative politeness strategy in realizing requests in DCT (see Tables $3 \& 4$ ).

Although the Ss dominantly used the negative politeness quantitatively in realizing their requests it did not occur across all the scenarios. They dominantly used it in five of the ten scenarios. There were $15(65 \%)$ of 23 in Scenario 2, 16 $(76 \%)$ of 21 in Scenario 3, $12(60 \%)$ of 20 in Scenario 4, $12(55 \%)$ of 22 in Scenario 5 , and $12(50 \%) 24$ in Scenario 9 of the dialogues containing requests realization by means of this strategy. Their selection of this strategy was not due to the sensitivity of the situational variables. They unnecessarily considered certain situational variables which were described as social distance and dominance when utilizing this strategy, for instance, they used it dominantly in Scenario 2: ask a fellow student to lend you a pen. For instance, one of the Ss used negative politeness to his/her fellow student.

Table 3 Distributions of query preparatory modals in DCT

\begin{tabular}{cccccccc}
\hline & \multicolumn{7}{c}{ Query Preparatory Modals } \\
Situations & May & Can & Could & Would & Do you (mind) & Others & Total \\
\hline 1 & 0 & 0 & 1 & 1 & 0 & 0 & 2 \\
2 & 22 & 6 & 1 & 3 & 4 & 0 & 36 \\
3 & 11 & 1 & 6 & 4 & 0 & 0 & 22 \\
4 & 0 & 3 & 14 & 13 & 1 & 0 & 30 \\
5 & 6 & 10 & 10 & 15 & 1 & 1 & 43 \\
6 & 0 & 0 & 2 & 2 & 0 & 0 & 4 \\
7 & 3 & 1 & 5 & 7 & 4 & 1 & 21 \\
8 & 1 & 0 & 2 & 2 & 1 & 0 & 6 \\
9 & 1 & 0 & 3 & 3 & 1 & 0 & 8 \\
10 & 0 & 4 & 6 & 5 & 1 & 1 & 17 \\
11 & 11 & 1 & 5 & 7 & 2 & 0 & 26 \\
12 & 5 & 1 & 3 & 6 & 0 & 0 & 15 \\
13 & 0 & 15 & 3 & 6 & 2 & 3 & 29 \\
14 & 0 & 12 & 12 & 7 & 6 & 0 & 37 \\
15 & 0 & 15 & 9 & 5 & 4 & 0 & 33 \\
Total & 60 & 69 & 81 & 86 & 27 & 6 & 329 \\
Average & .18 & .21 & .25 & .26 & .08 & .02 & 100 \\
\hline
\end{tabular}

(11) A: I am sorry / I don't / bring my pen / do you have one? / *an I borrow*?
B: *Oh yes / I have* / of course / of course you may // here's my pen.

A: Thank you very much. 
The $S$ in excerpt (11) even started the dialogue with "I am sorry..." and continued with "...do you have one?" to check on availability of the $\mathrm{H}$ in order not to enforce the $\mathrm{H}$. After giving this supportive move, he/she came to the request act. They attempt to save the Hs' negative face by checking on the Hs' ability and willingness to do the acts requested using query preparatory modals as listed in Table 3.

\section{d. Off-record Strategies}

The last strategy applied by the subjects was the off-record politeness. The subjects in using this strategy were essentially indirect uses of language: to construct an off-record utterance Ss said something that was either more general or actually different from what one meant (Brown \& Levinson, 1987: 211). It was used by some of the Ss. It was found only $2 \%$ of the subjects in DCT and $11 \%$ of those in roleplays. They used hints in their requests. The Ss dominantly used the off-record strategy in Scenario 8: ask a manager to accept you in a vacant position. Out of 18 dialogues in this scenario $78 \%$ of them used the offrecord strategy such as in (14).

(12) A: ... I have worked for / I have worked / in several companies.

B: Why do you / why do you want / to apply this position?

A: The career / is admired / than the other companies / so / I'm looking for the best firm.

B: Okay / I'll call you within this week.

A: Okay / thank you for acceptance.

The S only uttered "A: I have worked for / I have worked / in several companies" and in another part " $\mathrm{A}$ : The career / is admired / than the other companies / so / I'm looking for the best firm" Instead of saying, for instance, "would you employ me in your company I am qualified for this position?" he/she just made utterances that infer him/her as a person who was properly accepted in that company.
It was evidently found that the subjects utilized the off-record politeness dominantly in Scenario 8 due to the substance of the message in the requests that they had to enact. The Hs seemingly dominated the dialogues. The flows of the conversations were dependent on the Hs whose roles as managers. The Ss in this case just responded the Hs. In some dialogues, the Hs initiated the conversations while the Ss just answered to the Hs' questions. In short, the chances of realizing direct and conventional indirect strategies were limited to the Hs' queries. The Ss made some utterances partly referring to what they wanted to requests or they used hints instead.

\section{e. Combined Positive with Negative Politeness Strategies}

Some of the subjects did both redressive actions when they realized their requests. On the one hand, they save the Hs' positive face wants such as using some lexical or phrasal devices which expressed solidarity. It was shown by the ways they praised and gave approval to the Hs. On the other hand, they realized the request acts in the form of query preparatory, utterance containing reference such as ability using the modals can and could, willingness with would and other conventionalized components. Some of the subjects used this combination in some of their requests. Out of the 68 subjects in DCT and 36 subjects in roleplays $8 \%$ in DCT and $18 \%$ in role-plays utilized this combination.

In DCT questionnaires, for instance, one of the subjects initiated his/her request by praising the $\mathrm{H}$ before realizing his/her request such as the following example.

(13) Hi. How beautiful the way of your music! But could you help me please. I want to prepare anything for my examination tomorrow, so I have to study. Maybe next time we can play music together. Would you mind helping me? 
The way the $\mathrm{S}$ praised showed solidarity as if he/she had been familiar with the $\mathrm{H}$ or the utterance "Hi. How beautiful the way of your music!" and "Maybe next time we can play music together" was considered as a joke and an intimacy marker. These manners showed that the S saved the H's positive face want. Conversely, he/she used conventionally indirect strategy in enacting the request "Would you mind helping me?" As stated previously, the conventional indirectness was aimed to mitigate the imposition on the $\mathrm{H}$ (see Table 4).

Further in role-plays, it was observed clearly. The Ss more possibly manipulated their requests using both positive and negative politeness strategies in certain dialogues. This combination was found more in the Role-plays than those in DCT. They combined the strategies within the turns as shown in (13).

(14) A: MAM // I'd like to / consult / consult my / paper // I am going to have / eh / I am going to have

B: Have what?

A: The final examination / so / really need your / advisory / Can you help me / MAM?

B: Have you made an appointment with me before?

A: ...

B: ...

A: Okay / thank you.

Table 4 Distributions of query preparatory modals in role-plays

\begin{tabular}{ccccccc}
\hline \multirow{2}{*}{ Situations } & May & Can & Could & Would & Do you (mind) & Total \\
\hline 1 & 4 & 10 & 1 & 0 & 0 & 15 \\
2 & 5 & 8 & 2 & 2 & 1 & 18 \\
3 & 0 & 12 & 1 & 1 & 0 & 14 \\
4 & 0 & 7 & 1 & 8 & 0 & 16 \\
5 & 0 & 9 & 2 & 0 & 1 & 12 \\
6 & 0 & 0 & 0 & 3 & 2 & 5 \\
7 & 0 & 4 & 0 & 5 & 4 & 13 \\
8 & 0 & 0 & 0 & 0 & 0 & 13 \\
9 & 3 & 8 & 0 & 2 & 0 & 11 \\
10 & 6 & 3 & 1 & 1 & 0 & 117 \\
Total & 18 & 61 & 8 & 22 & 8 & 100 \\
Average & .15 & .52 & .07 & .19 & .07 & 0 \\
\hline
\end{tabular}

The utterance "MAM // I'd like to / ... / consult my / paper" was a hedged performative which was usually realized in direct manner rather than indirect one. The $S$ felt optimistic that the request would be felicitous. That is why the $\mathrm{S}$ utilized positive politeness strategy. However, in another part the S uttered "... Can you help me/MAM?" which referred to the H's ability to do the act requested. He/she utilized query preparatory which is grouped in to negative politeness strategy.

In Summary, the subjects used the negative politeness strategy most frequently, $85 \%$ of the 995 request realizations in DCT and $43 \%$ of the 203 dialogues in role-plays and then followed by the positive politeness strategy (23\% in DCT and 3\% in Role-plays), off-record strategy $(11 \%$ in DCT and $2 \%$ in Roleplays), and Bald-on-record strategy (2\% in DCT and $2 \%$ in Role-plays). It was also found that some subjects combined both positive and negative politeness strategies when realizing requests. The occurrence of this combination contributes significantly to the distributions, i.e. $18 \%$ in DCT and $8 \%$ in Role-plays as illustrated in Figure 1.

\section{Native-norms Transfers}

In addition, many of the subjects started the dialogues using 'Excuse me' as polite 
attention getters or as alerter, continued with supportive moves, and came to head acts of the requests like in (3) and (10). They evidently formed different patterns from those of native speakers. They applied the patterns of attention getters (excuse me, address terms, etc.) supportive moves - head acts. The native speakers, conversely, applied attention getters - head act - supportive moves (Blum-Kulka \& Olshtain, 1986:204). The difference is due to the subjects' culturespecific L1 backgrounds. The speakers of Asian languages in which Indonesian is one of them, used the inductive pattern of reasoning, i.e. to delay the point to the end (Yuxin \& Cheng, 2002). This pattern assembles the ways they realize English requests. They may realize the requests with correct English in term of grammar use, but inappropriate in term of pragmatics.

The indirectness in realizing requests done by the subjects had something to do with the attempts to avoid face-threatening acts. The subjects tried to reduce the amount of face-threat by utilizing appropriate ways. They selected certain strategies for this purpose. Of the five politeness strategies, they utilized the negative politeness strategy most frequently. They saved the Hs' negative face, i.e. considering the recipients' right not to be imposed. The indirectness offered options whether or not to comply with the requests and tried to make the $\mathrm{Hs}$ feel good. These pertained to Lakoff's (1990) principles, i.e. 'Don't impose' (rule 1), 'Give options' (rule 2), and 'Make a feel good, be friendly' (rule 3). Besides, one of the principles of negative politeness was to realize the requests using the conventional indirectness, in fact, most of them utilized this strategy most frequently in their requests. So it indicated that the indirectness resembled in politeness. In other words, one of the reasons to use the conventionally indirect strategy was to save the Hs' negative face. Indirectness made the $\mathrm{Hs}$ not to be impinged or seemingly not obliged to comply with the requests.

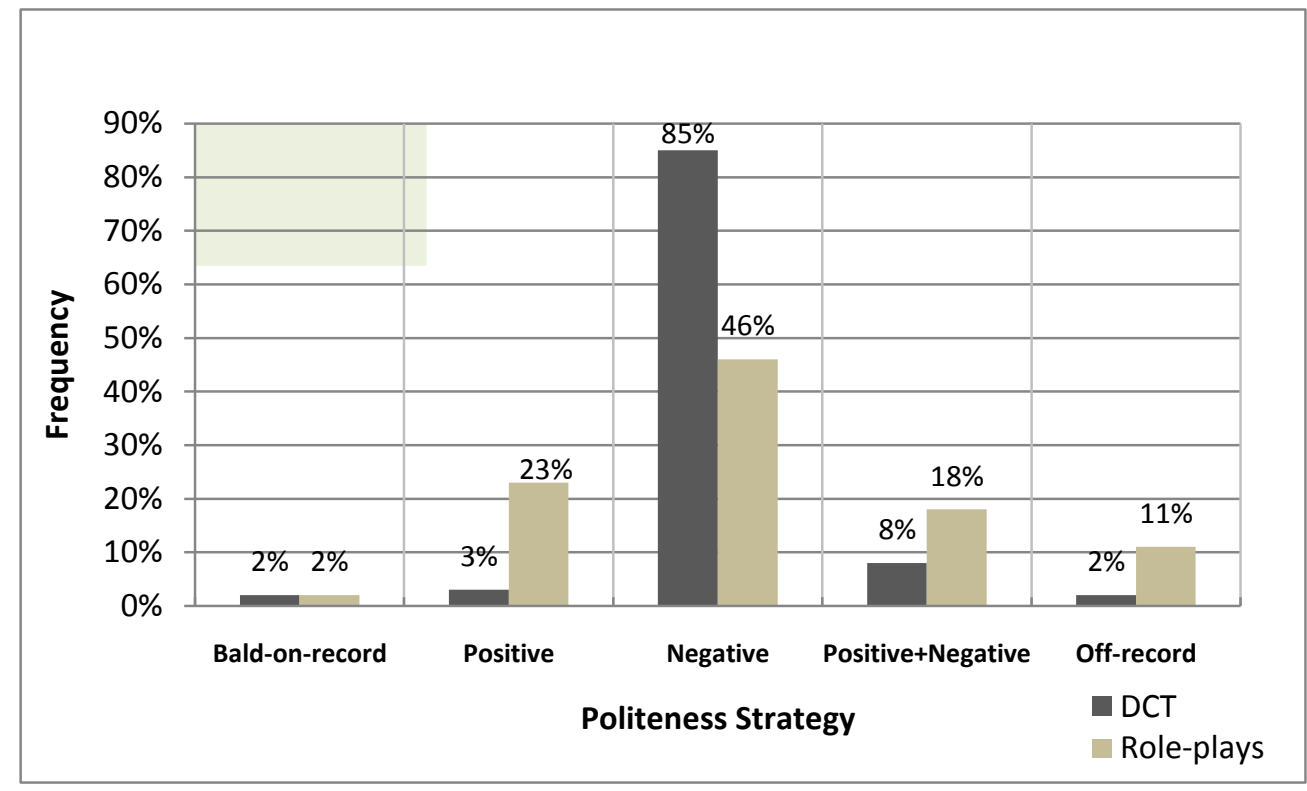

Figure 1: Graph of Strategy Frequency in DCT and Role-plays

The negative politeness occurred dominantly was apparently transferred from the subjects' native culture. Indo- nesian cultural norms which considered much deference in speech act realizations assemble their ways of making requests. 
The Ss highly respect Hs. They tended to neglect the situational variables in utilizing their politeness strategies. They used the negative politeness strategy most frequently in all the situations in DCT and most scenarios in role-plays. They even used negative politeness when making requests to their fellows like in Situations 7: ask a fellow student to share a textbook. Of the 66 request realizations, there were 55 requests realized using the negative politeness as shown in (15) and (16).

(15) I don't bring my textbook with me. So, do you mind I we see the textbook together?

(16) Could you share this book with $m e$ ? Coz I didn't bring it.

Though the situational variables made them possible to realize their request using other politeness strategy types most of them steadily used the negative politeness. They got accustomed to saving others' negative face, not to oblige others to do the acts requested. Further, in hierarchical status-conscious societies like Indonesian in general the negative politeness strategies are much in evidence (Foley, 1997). Consequently, they used the query preparatory modals (can, could, would and do) competitively in their requests as shown by most examples previously to keep this polite manners.

In particular, some of them even used please in their mood derivable as the direct strategy and considered as bald-on-record strategy such as (1)" Turn down the music, please" and (2) "Please turn the music down". They, though, did not use redressive actions they embedded their requests with this politeness marker. This was also a sort of cultural transfers though native speakers of English did the same things in certain situations. They actually realized these two requests under the situations in which they were disturbed by the Hs' actions. This request strategy, as its name 'mood derivable', derived from the
Ss' mood, but in fact they necessarily embedded please in their requests as also shown in excerpt (17).

(17) A: ...So / please! / I need your / your attention / to help me / because / this final exam / - my thesis is very important for me / so / please / turn off / turn off your radio.

B: Sorry / okay / I will turn off my radio.

A: It's okay / Thank you very much.

Other pragmatic transfers which were politeness motivated were the ways they initiated the request realizations. Many of the subjects used 'Sorry' or 'I am sorry' instead of 'Excuse me' as the attention getters while the native speakers of English did not start the requests in such a way. 'Sorry' is commonly used to express sorrow, regret, or penitence (MerriamWebster, 1985:1126), for instance, "I'm sorry to hear that" to express condolences. The following are the examples of requests using 'sorry' as the polite attention getters.

(18) Sorry, I have to study for a midterm examination tomorrow. So, can you turn down the music?

(19) I am sorry. May I borrow your pen, please?

The uses of 'sorry' were actually inappropriate in the context in which the Ss did not mean to express sorrows or regrets. In fact, they transferred the term 'maaf' in Indonesian to their requests. The natives of Indonesian often used the term 'maaf' to avoid FTAs or at least to reduce the impositions to others when doing with words. The subjects in this case realized in such a way in responding to the DCTquestionnaires. These sorts of construction were apparently found in every situation.

(20) Hi. How beautiful the way of your music! But could you help me please. I want to prepare anything for my examination tomorrow, so I have to study. Maybe next time we 
can play music together. Would you mind helping me?

(21) A: MAM // I'd like to / consult / consult my / paper // I am going to have / eh / I am going to have

B: Have what?

A: The final examination / so / really need your / advisory / Can you help me / MAM?

B: Have you made an appointment with me before?

A: Actually / I have / I have / but / eh / you never / you never answered my / call and never answered my SMS (short message service) / so / I decided / I decided to meet you / by myself.

B: Okay / just put it there.

A: Thank you / when will / you check my

B: I'll return it to you / next week.

A: So / cannot be faster / MAM!

B: eh / wait / wait! / Tomorrow! / *Tomorrow! / Tomorrow!*

A: $*$ Oh / please MAM!* I have very limited time.

B: Okay / I'll return it you / on Friday.

A: Okay / thank you.

The last transfers occurred in the form of combining positive with negative politeness strategies. Some of the subjects applied both reddressive actions in realizing certain requests as in (20). The $S$ started the request with friendly expression such as "How beautiful the way of your music! ...Maybe next time we can play music together" but executed with "Would you mind helping me?" as the head acts. Others might necessarily save the recipient positive face by showing their optimistic like in (21) "MAM // I'd like to / consult / consult my / paper // I am going to have / eh / I am going to have", but in another turn he/she save the H's negative face by uttering "... / Can you help me / MAM?" This sort of combination occurred in some request realizations as elaborately exposed in the following examples.

(22) Friend, can you help me? I don't really understand this subject. Can you explain more about that?

(23) Hello. My friend. I think you're clever in class and smart even than me. So, would you like to help me to get ready for my exam?

In fact many request realizations applied the combination were found in Situation 10 as shown in examples (22) to (23) and in Situation 14 as shown in (24) to (25).

(24) Hi, brother. Can you show me this address? I don't recognize the places well. I just have this name card. Can you help me?

(25) Excuse me, friend. Do you know the address that you see in this name card? Can you show me the place? Sorry, I'm bothering you.

They commenced their requests using solidarity in-group identity markers such Friend, Hi friend, Hello my friend, Hi brother, Excuse me sister, and Excuse me friend. The Ss used these markers to save the Hs' positive face. However, when accomplishing the head acts they switched to save the Hs' negative face applying the conventional indirectness. These sorts of combination occurred in some of request realizations, $8 \%$ in DCT and $12 \%$ in Roleplays.

\section{CONCLUSION}

The request strategies chosen by the ILE are politeness-motivated. They utilize indirect strategies because they want to be polite in realizing their requests to Hs. They do FTA in realizing their requests. 
They make use of bald-on, positive politeness, negative politeness, and offrecord strategies. They commonly use the query preparatory which is grouped in the conventionally indirect strategy to save the Hs' negative face, i.e. the right not to be imposed. This sub-strategy resembles the negative politeness strategy. They utilize the query preparatory and apply the negative politeness simultaneously. In short, they dominantly employ the negative politeness strategy in realizing requests.

Besides, they also combine the positive with negative politeness in some of their requests using the query preparatory. On the one hand, they save $\mathrm{Hs}$ positive face wants, i.e. the $\mathrm{H}$ needs approvals and praises, for instances, to be greeted friendly and exaggerated properly. They feel optimistic that the $\mathrm{Hs}$ will comply with the requests. On the other hand, they attempt to save the Hs' negative face by checking on the Hs' ability and willingness to do the acts requested using query preparatory modals.

The typical indirectness and politeness strategies apparently are applied by the ILE are due to the L1-norm transfers. They, whose Indonesian language and cultures as their L1 and C1 background, employ their native manners when they realize their TL requests. They dominantly modify their requests externally and most of the external modifications in their indirectness are made in inductive patterns. They embed most of the supportive moves before the head acts and some even insert the moves in both before and after the head acts. It, further, indicates that they apply cyclical patterns of thinking. They realize requests in English, but with Indonesian ways of grounding, getting pre-commitment, checking availability on $\mathrm{Hs}$, disarming, and sweetening.

\section{REFERENCES}

Blum-Kulka, S., House, J. \& Kasper, G. (Eds). (1989). Cross-cultural pragmatics: Request and apologies. Norwood, New Jersey: Ablex Publishing Corporation.

Blum-Kulka, S. \& Olshtain, E. (1986). Too many words: Length of utterance and pragmatic failure. Studies in Second Language Acquisition, 8, pp. 47-61.

Blum-Kulka, S. (1992). Indirectness and politeness in requests: Same or different? Journal of Pragmatics, 11(1), pp. 131-146.

Bonvillain, N. (2003). Language, Culture, and communication: The meaning of messages. Upper Saddle River, New Jersey: Prentice Hall.

Brown, P. \& Levinson, S.C. (1987). Politeness: Some universals in language usage. Cambridge: Cambridge University Press.

Faerch, C. \& Kasper, G. (1989). Internal and external modification in interlanguage request realization. In Blum-Kulka, S., House, J. \& Kasper, G. (Eds), Cross-cultural pragmatics: Request and apologies. Norwood, New Jersey: Ablex Publishing Corporation.

Foley, W. A. (1997). Anthropological linguistics: An introduction. Malden, Massachusetts: Blackwell Publishers Inc.

Lakoff, R. T. (1990). Talking power: The politics of language in our lives. Glasgow: Harper Collins.

Leech, G. (1983). Principles of pragmatics. London: Longman.

Merriam-Webster. (1983). Webster's ninth new collegiate dictionary. Springfield, Massachusetts: Merriam-Webster Inc.

Yuxin, J. \& Cheng, C. (2002). Indirectness in Chinese English Writing. Asian Englishes 5(1), pp. 64-74. 
Appendix 1

\section{DCT Questionnaires \\ Instruction}

I would like to ask you to help me by answering the following questions concerning with requests. This is not a test so there is no "right" or "wrong" answer and you don't even have to write your name on it. Please give your answers sincerely as only this will guarantee the success of the investigation. Thank you very much for your help.

Imagine that you are in the following situations in an English speech community.

\section{Situation 1:}

You are preparing for a mid-term examination which is scheduled tomorrow. It's about 9 p.m. A new neighbor about your age whom you do not already know is playing music very loudly. So you cannot concentrate on your studying. You want this neighbor to turn down the music.

What would you say to get the neighbor to do this favor?

\section{Situation 2:}

You are reading a book at a library. When you want to take notes you realize that you do not have a pen with you. A young person about your age whom you do not already know is sitting and reading a book next to you. You want to borrow a pen from this person.

What would you say to get this person to do this favor?

\section{Situation 3:}

You are very much interested in taking a course, but you notice that this course requires a prerequisite course. Although you do not meet this requirement and do not already know the lecturer, you want to ask the lecturer to allow you to take this course.

What would you say to get the lecturer to grant you permission to take this course?

\section{Situation 4:}

You are on your way to a school building and your hands are both so full that you need someone to open the door for you. You notice that a person about forties whom you do not already know is standing nearby the door, and you see no other people near you. So you want to ask this person to open the door for you.

What would you say to get this person to do this favor for you?
TOEFL-like Scores:

\section{Situation 5:}

A friend of yours from out of town is paying you a visit. You are showing your friend around the campus and both of you would like to take a photo together to keep memory of this happy moment. So you want to ask a nearby student whom you do not already know to do you this favor.

What would you say to get this student to take your picture together?

\section{Situation 6:}

Your final exams are approaching and you find that the scheduled date of one subject is the same date as that of your brother's wedding. You cannot do both that day and you prefer to join this unforgettable moment of your family. So you want to ask your lecturer to rearrange another day especially for you to take this final exam.

What would you say to get your professor to allow you to take the exam on another day?

\section{Situation 7:}

You realize that you have left your textbook at home. The fellow student sitting next to you has the textbook open in front of you and is following the lesson. You want the fellow student to share the textbook.

What would you say to get him to share with you?

\section{Situation 8:}

You did not come into the class last week because of sickness. It was the first meeting for this class last week, so you do not already know the lecturer. You did not get the handout that was distributed in the first meeting. The lecturer is approaching you now, so this is a good chance to talk to. You want to borrow the handout from the lecturer.

What would you say to get the lecturer to lend you the handout?

\section{Situation 9:}

You are asked to submit the final paper a week after the last meeting of this semester. You do not think that you can finish on the due day. You want the lecturer to extend the deadline.

What would you say to get this lecturer to extend the due day? 


\section{Situation 10:}

You are preparing for upcoming final exams and find that one class is really difficult for you. A fellow student seems to understand the class much better than you. So you need to ask this fellow student to help you get ready for the exam. What would you say to get this student to help you out?

\section{Situation 11:}

You are very much interested in sitting in one class taught by a lecturer whom you have studied with before. So you need to ask for the lecturer's permission to sit in. What would you say to get this lecturer to allow you to sit in this class?

\section{Situation 12:}

You missed one topic in a course you enrolled in, so you want to borrow a fellow student's notes to catch up with the rest of the class.

What would you say to get this student to lend you notes for the class you missed?

\section{Situation 13:}

You are in a mall to have a 'window shopping'. While walking along the dress showroom, you find a lot of nice T shirts with marked ' $30 \%$ discount'. You get interested in buying one. You want to buy one, but you get difficulty in finding the suitable size. A young (younger than you) shop assistant is approaching you. It is a good chance for you to ask the assistant to find the one that is suitable for you. What would you say to ask the shop assistant to do this favor?

\section{Situation 14:}

You just arrive in a big city in which you do not recognize the places well. You want to see a person whose office in the city. You have the address written on the person's name card with you. Accidentally, you see a teenager walking on the path then you want to ask the teenager to tell you how get to the place.

What would you say to ask the teenager to help you out?

\section{Situation 15:}

You want to see a school principal. You need to ask someone to show you the principal's office. In the front gate, you see some students chatting. It is a good chance for you to ask one of them to help you see the principal.

What would you say to one of the students to do this favor? 
Appendix 2: Role-plays

\section{Role Plays}

Instruction: Read the scenarios carefully and try to comprehend the contents and roles of the interlocutors in them. Demonstrate a dialogue of each scenario below with your fellow student.

\section{Scenario 1:}

You want to go home in a hurry after the class because of dropping off your father to station to leave for out of town. You will be late if you take a bus from the campus. Fortunately, you see a fellow student riding a motor cycle. It is a good chance for you to ask the fellow student to give a ride home.

\section{Scenario 2:}

You are in a class. The lecture is about to start. You realize that you do not have a pen with you. You want to borrow a pen from a fellow student who is sitting next to you.

\section{Scenario 3}

You are preparing a final paper for your class. Your lecturer recommends you to go to library to find a book related to my paper topic. Now you are in a school library to look for the book. However, you have difficulty in finding the book, so you want the librarian whom you already know to help you out.

\section{Scenario 4:}

You are reading to prepare your final exams. A new neighbor about your age who stays next door in your apartment is playing music loudly. It is very hard for you to concentrate on your studying. You do not already know the neighbor because of newly moving to this apartment. You need to ask the neighbor to turn down the music.

\section{Scenario 5:}

You are in a downtown to find an office in which you are going to have a job interview. You need someone to help you find the place. Fortunately, you see a teenager walking along the path, so you approach the teenager and ask for this favor.

\section{Scenario 6 :}

You are completing your final paper or skripsi. You want to see and consult with your advisor about the paper. You see the advisor coming to the office. It is a good chance for you to have a consultation.

\section{Scenario 7:}

There is a good movie during the weekend. You plan to go seeing the movie. You feel that will be more interesting if you go with your friend, so you ask your close friend to see the movie together with you.

\section{Scenario 8:}

You are in an office to apply a job. You want to be accepted by the manager in the vacant position. Now you are answering to the questions in the interview and convincing the manager of your capability.

\section{Scenario 9:}

You are in a shoe store. You plan to buy a pair of shoes. After noticing some of the shoes in the showroom, you get interested in a certain pair of shoes. Of course, you need to try on the shoes. You see the shop assistant and ask for doing this favor.

\section{Scenario 10:}

You are in a music store and want to buy a cassette. After you get the cassette that you would like to buy, you need to ask the shop assistant to let you try on listening to it. You already know the shop assistant, since you have been to this store for several times before. 